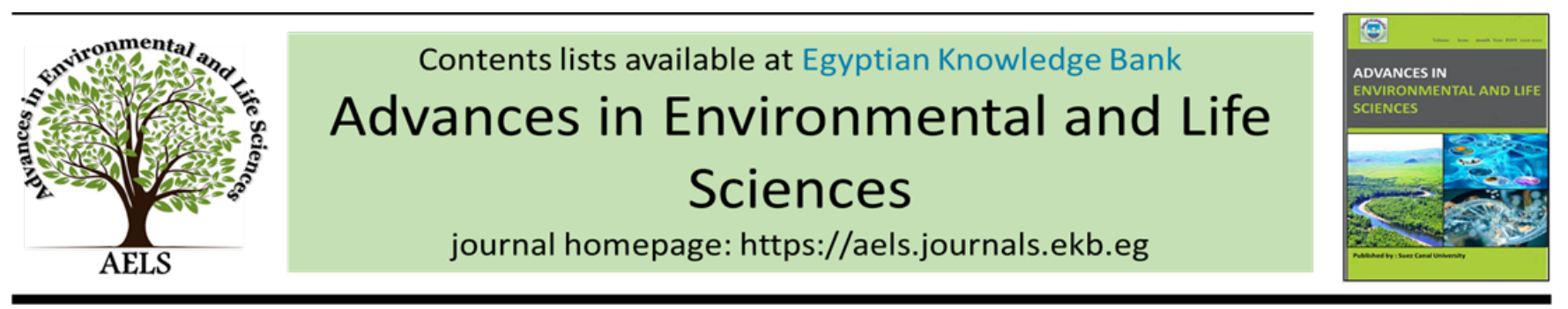

\title{
Modern View for Binary and Ternary Complexes of Metal Ions with Amoxicillin and some Amino Acids
}

\author{
Adel S Orabi, Abbas M Abbas, Manar A Abd Elraoof*, Gasser M Khairy \\ Chemistry Department, Faculty of Science, Suez Canal University, 41522, Ismailia, Egypt
}

\section{Graphical Abstract}
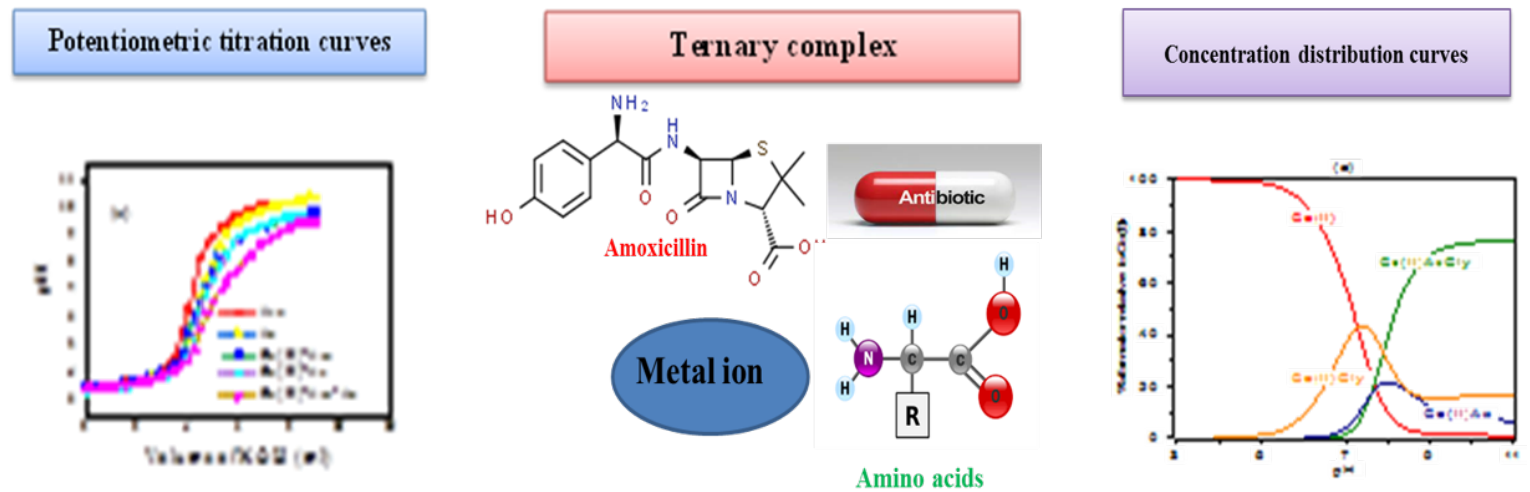

\section{Abstract}

Antibiotics have saved countless lives and continue to be the backbone for treating bacterial infections. $\beta$-Lactam antibiotics have been successfully introduced as antibacterial agents in the early 1950s. They are still the most popular drugs for treating bacterial infections of many diseases. As a result, the biological applications of these compounds and their complexes have attracted remarkable attention as they can be used as antibacterial and anticancer agents. From this point, the interactions of metal ions ( $\mathrm{Cu}$ (II), Co (II), Ni (II), Zn (II), $\mathrm{Eu}$ (III), and $\mathrm{Tb}$ (III) with amoxicillin( $\left.\mathrm{H}_{2} \mathrm{Ax}\right)(\mathrm{Ax})$ and some selected amino acids (L-glycine (Gly), L-methionine (Met), L-asparagine (Asn), L-histidine (His) and DL-alanine (Ala) have been investigated potentiometrically, $0.1 \mathrm{M} \mathrm{KNO}$ ionic strength, in an aqueous medium at $20^{\circ} \mathrm{C}$. The dissociation constants and formation constants of ligands and their metal complexes were calculated from potentiometric data using the Irriving-Rossotti method. The acid-base characteristics of ligands have been examined and discussed. It was found that complexes formed were of (1100) and (1110) type. The mechanism of ternary complexes formed is association manner. It has been found that amoxicillin does as a primary ligand for the interaction of metal ions in the presence of glycine, alanine, or histidine amino acids. On the other hand, in the case of methionine or asparagine, amoxicillin acts as a secondary ligand. Stabilities of ternary complexes to metal ions were in the following order: $\mathrm{Zn}(\mathrm{II})<\mathrm{Cu}(\mathrm{II})>\mathrm{Ni}(\mathrm{II})>\mathrm{Co}(\mathrm{II})$ for transition metal ions and $\mathrm{Eu}(\mathrm{III})$ $>\mathrm{Tb}(\mathrm{III})$ for lanthanide metal ions. The concentration distribution curves of the binary and ternary complexes formed in the solution were evaluated as a function of $\mathrm{pH}$ using the HYSS program.

Keywords: Amoxicillin, amino acids, binary complexes, ternary complexes, potentiometry, stability constant, distribution curves

\footnotetext{
* Corresponding author

E-mail address: manar_abdelhameed@Science.Suez.edu.eg
} 


\section{Introduction}

During the past decades, the use of metal complexes as pharmaceuticals has gained significant interest due to their therapeutic applications [1]. The transition metal complexes with nitrogen and oxygen donor ligands have multi applications such as anticancer, anti-tubercular, antibiotic, antimicrobial, and antifungal agents [2, 3]. The interaction of metal ions with ligands to form more potent complexes has a significant interest in coordination chemistry. Lanthanide complexes are used in cancer detection and treatment due to the magnetic and chemical characteristics of the lanthanide-ion $(\operatorname{Ln}(\mathrm{III}))$. Tri-positive lanthanides are characterized by high charge to volumes ratios, which enable the $\operatorname{Ln}($ III) to form adenovirus complexes, and so various Ln(III) compounds were studied in vivo and in vitro regarding their potential for improving the transduction effectiveness for adenovirus vectors [4]. Lanthanides have just been widely employed as bioimaging agents in the detection of cancer. Amino acids are necessary for biological bodies, and the complexation behavior of transition metal ions with amino acids and peptides has significant biological importance $[5,6]$.

Ternary complexes serve important roles in biological processes by storing and transporting active substances across cell membranes. These phenomena are strongly related to the formation of higher-order complexes. Therefore, the stability of complexes has major importance as it can affect complexes' biological and chemical activity $[7,8]$.

In recent years, the chemistry of $\beta$-lactam antibiotics about their bioactivities has been of considerable interest [9-11]. The antimicrobial activity of aminopenicillin drug and its metal complexes has been discussed in several literatures $[12,13]$. Studies performed on the aminopenicillin drug, and its metal complexes have much physiological and pharmacological importance because the metal complexes of the drug are more potent than the drugs themselves [14].

Amoxicillin $\quad\left(\mathrm{H}_{2} \mathrm{Ax}, \quad 6\right.$-(2-amino-2-(4hydroxyphenyl) acetamido)-3,3dimetyl-7-oxo-4-
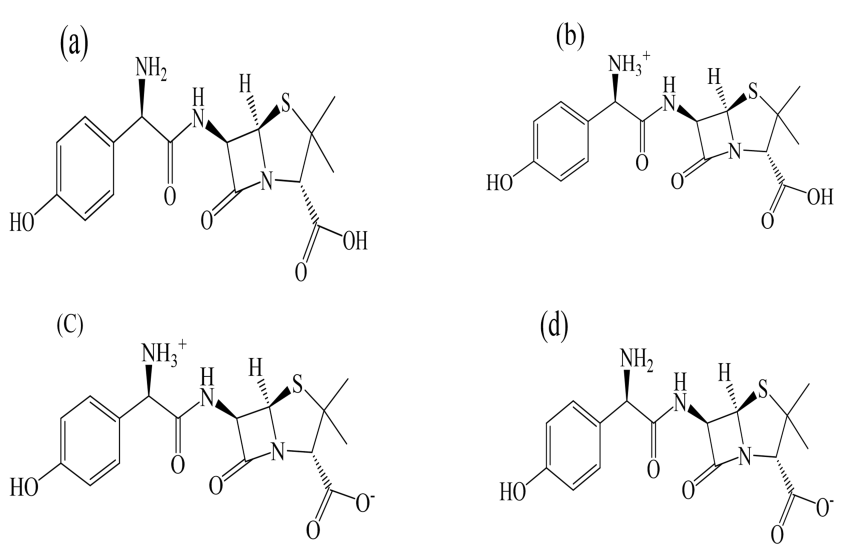

Figure 1: Structures of Amoxicillin at different $\mathrm{pH}$ (a)Amoxicillin at solid state $\left(\mathrm{H}_{2} \mathrm{Ax}\right)$, (b) Amoxicillin at $\mathrm{pH}<3\left(\mathrm{H}_{3} \mathrm{Ax}^{+}\right)$, (c) Amoxicillin at $\mathrm{pH}$ 3-7.5 $\left(\mathrm{H}_{2} \mathrm{Ax}^{ \pm}\right)$, (d) Amoxicillin atpH 7.5-10 $\left(\mathrm{HAx}^{-}\right)$

thia-1-azabicyclo[3,2,0] [2, 3]heptane-2-carboxylic acid) is a very effective penicillin antibiotic that is gaining popularity [15]. It may be found in an aqueous medium as a cation $\left(\mathrm{H}_{3} \mathrm{Ax}^{+}, \mathrm{pH}\right.$ $<3)$, zwitterion $\left(\mathrm{H}_{2} \mathrm{Ax}^{ \pm}, \mathrm{pH} 3-7.5\right)$, or anion $\left(\mathrm{HAx}^{-}, \mathrm{pH}\right.$ 7.5-10) [15], [16] as shown in figure (1). Amoxicillin is quite similar to dipeptides in chemical structure and may form stable complexes with metal ions due to their acid-base characteristics.

Amoxicillin is a bactericidal agent acting against susceptible microorganisms by inhibiting cell wall biosynthesis during bacterial multiplication [17, 18]. In both aqueous and methanolic solutions, amoxicillin may make complexes with metal ions [19, 20]. Amoxicillin's coordination molecules, like those of other penicillins, are still understudied by bioinorganic chemists [16], so it was interesting to study the interaction of amoxicillin as a ligand with some metal ions(which have high biological activity) in an aqueous solution.

Research on amoxicillin complexes might be a critical step in developing new treatments to combat antibiotic resistance. Thus, the aim of the present work was the study of the interaction of metal ions ( $\mathrm{Cu}(\mathrm{II}), \mathrm{Co}(\mathrm{II}), \mathrm{Ni}(\mathrm{II}), \mathrm{Zn}(\mathrm{II}), \mathrm{Eu}(\mathrm{III})$, and $\mathrm{Tb}(\mathrm{III})$ with amoxicillin(Ax) and some selected amino acids potentiometrically at $20{ }^{\circ} \mathrm{C}$ and ionic strength $0.1 \mathrm{M} \mathrm{KNO}_{3}$ in the aqueous medium. The dissociation constants and forma- 
tion constants of ligands and their metal complexes were calculated from potentiometric data using the Irriving-Rossotti method [21].

\section{Experimental}

\subsection{Materials}

All compounds used were analytical-grade reagents that were not purified further. Amoxicillin (Ax) and amino acids (L-glycine (Gly), L-methionine (Met), L-asparagine (Asn), Lhistidine (His), and DL-alanine (Ala)) were obtained from the Sigma Chemical Company. The chemical structures of amino acids under study were shown in scheme (1). Potassium hydroxide $(\mathrm{KOH})$ was prepared and standardized against a potassium hydrogen phthalate solution (Merck AG). Nitric acid solution was prepared and titrated against standardized potassium hydroxide solution. Metal salts used in this work were: $\mathrm{CuCl}_{2} \cdot 2 \mathrm{H}_{2} \mathrm{O}, \mathrm{EuCl}_{3} \cdot 6 \mathrm{H}_{2} \mathrm{O}$, $\mathrm{TbCl}_{3} \cdot 6 \mathrm{H}_{2} \mathrm{O}, \mathrm{NiCl}_{2} \cdot 6 \mathrm{H}_{2} \mathrm{O}, \mathrm{Zn}\left(\mathrm{NO}_{3}\right)_{2} \cdot 6 \mathrm{H} 2 \mathrm{O}$, and $\mathrm{Co}\left(\mathrm{NO}_{3}\right)_{2} \cdot 6 \mathrm{H}_{2} \mathrm{O}$. Stock solutions of metals were standardized complex-metrically by ethylenediamine tetra acetic acid disodium salt (EDTA) titrations. The ionic strength was adjusted by using a solution of $0.1 \mathrm{M} \mathrm{KNO}_{3}$. Doubly distilled water was used for the preparation of all solutions.

\subsection{Apparatus}

Potentiometric $\mathrm{pH}$ data were obtained using a commercial Fisher electrode model $825 \mathrm{MP}$ at $20.00 \pm 0.100{ }^{0} \mathrm{C}$. The pH-meter has been standardized daily using buffer solutions of $\mathrm{pH} 4.01$ and $\mathrm{pH}$ 9.20. Fisher Scientific Circular model 9000 water thermostat has been used to adjust the temperature, and it has been held around $0.1^{\circ} \mathrm{C}$ of ideal. A magnetic stirrer was used to efficiently stir the solution.

\subsection{Procedure}

The following are the scheme used for constructing the calibration curves in order to calculating the dissociation constants of ligands and stability constants of binary and tertiary complexes as the following:
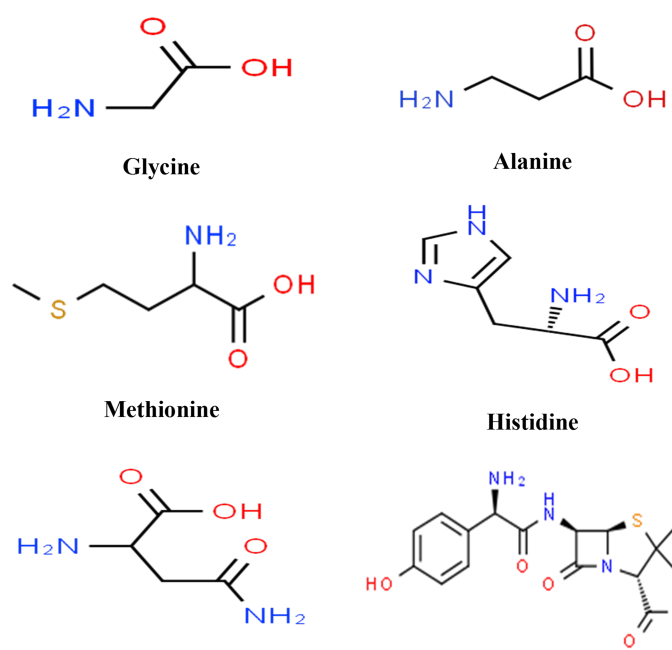

Asparagine

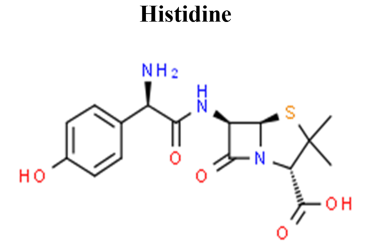

Amoxicillin

Scheme 1: Chemical structures of Amino Acids and Antibiotic

A- $\mathrm{HNO}_{3}\left(4 \times 10^{-4} \mathrm{M}\right)+\mathrm{KNO}_{3}(0.1 \mathrm{M})$ solution.

B- Solution a + AA $\left(1 \times 10^{-4} \mathrm{M}\right)$ (free amino acids).

C- Solution $\mathrm{a}+\mathrm{Ax}\left(1 \times 10^{-4} \mathrm{M}\right)$ solution (free amoxicillin).

D- Solution b + Metal ion $\left(1 \times 10^{-4} \mathrm{M}\right)$, binary system (metal-amino acids).

E- Solution $\mathrm{c}+$ Metal ion $\left(1 \times 10^{-4} \mathrm{M}\right)$, binary system (metal-amoxicillin).

F- Solution a + AA $\left(1 \times 10^{-4} \mathrm{M}\right)+$ Metal ion $\left(1 \times 10^{-4} \mathrm{M}\right)+\mathrm{Ax}\left(1 \times 10^{-4} \mathrm{M}\right)$, ternary system.

The total volume of the titrant has been kept being $25.00 \mathrm{ml}$. A constant ionic strength has been adjusted to be $0.10 \mathrm{M}$ using $\mathrm{KNO}_{3}$. For all titrations, the concentration of $\mathrm{HNO}_{3}$ has been adjusted to be $4.00 \times 10^{-4} \mathrm{M}$ at the beginning of titration in order to fully protonated the ligands.

Table 1: Dissociation constants of the ligands at $\mathbf{I}=$ $0.1 \mathrm{M} \mathrm{KNO}_{3}$ and $20{ }^{\circ} \mathrm{C}$.

\begin{tabular}{ccr}
\hline Ligand & $\mathrm{pKa}_{1}$ & $\mathrm{pKa}_{2}$ \\
\hline Alanine & - & 9.50 \\
Asparagine & - & 8.82 \\
Histidine & 6.14 & 10.37 \\
Methionine & - & 9.39 \\
Glycine & - & 9.49 \\
Amoxicillin & 7.16 & 9.74 \\
\hline
\end{tabular}




\section{Result and discussion}

\subsection{Dissociation constants of ligands:}

Amoxicillin contains three sites that may reversibly dissociate a proton to form a negativecharged anion. Amoxicillin may discharge one proton from the carboxylic group, one from the amine group $\mathrm{pKa}(7.16)$, and one from phenol group $\mathrm{pKa}(9.76)$. The values of the dissociation constants for Amino acids and Amoxicillin are listed in (table 1). In L-Histidine, two dissociation constants of $\mathrm{pKa}_{1}=6.14$ and $\mathrm{pKa}_{2}=10.37$ were obtained, which are associated with dissociation of imidazole nitrogen and the amino group of the ligand, respectively. L-glycine, DL-alanine, L-methionine, and L-asparagine dissociated protons from amino groups $\mathrm{pKa}=9.49,9.50,9.36$, and 8.82 , respectively. The ionization steps (a) and (b) are as follow:

Ionization steps of amoxicillin and L-histidine

$$
\begin{aligned}
& \mathrm{H}_{3} \mathrm{~L}^{+} \leftrightarrow \mathrm{H}_{2} \mathrm{~L}^{ \pm}+\mathrm{H}^{+} \\
& \mathrm{H}_{2} \mathrm{~L}^{ \pm} \leftrightarrow \mathrm{HL}^{-}+\mathrm{H}^{+} \\
& \mathrm{HL}^{-} \leftrightarrow \mathrm{L}^{-}+\mathrm{H}^{+}
\end{aligned}
$$

Ionization steps of alpha-amino acids

$$
\mathrm{H}_{2} \mathrm{~L}^{+} \leftrightarrow \mathrm{HL}^{ \pm}+\mathrm{H}^{+}
$$$$
\mathrm{HL}^{ \pm} \leftrightarrow \mathrm{L}^{-}+\mathrm{H}^{+}
$$

The first dissociation constant for the Ligands is very low $(<2.5)$ and dissociates in strongly acidic solutions. Therefore, these values could not be measured and obtained through the calculations.

\subsection{Binary Complex Formation Equilibria}

Amoxicillin and amino acids were titrated in the absence and presence of metal ions. It was observed that titration curves of the metalcomplexes were lower than those of the free ligands curves (figures 2-6), indicating that complex formation is associated with the release of the proton $\left(\mathrm{H}^{+}\right)$. Formation constants were calculated using the Iriving-Rossotti method and were presented in table 2 . From the titration curves, ${ }^{-} \mathrm{n}$ (the average number of ligand molecules attached per metal ion) and pL (the free ligand exponent) values have been calculated. It has been found that the value of $(\mathrm{n})$ was changed from 0.1 to 1.0 , indicating that complexes formed in solution are of type (1100). The following equations can represent the formation of binary complexes:

$$
\begin{aligned}
& \mathrm{M}+\mathrm{H}_{2} \mathrm{~L}^{+} \leftrightarrow \mathrm{ML}+2 \mathrm{H}^{+}(1) \\
& \mathrm{Or} \\
& \mathrm{M}+\mathrm{H}_{3} \mathrm{~L}^{+} \leftrightarrow \mathrm{ML}+3 \mathrm{H}^{+}(2)
\end{aligned}
$$

\subsection{Ternary Complex Formation Equilibria}

It is well known that when a solution contains two different ligands with a metal ion, they may exist in equilibrium either that (i) both the ligands ligate to the metal ion simultaneously (Association mechanism) (eq:5) or (ii) the two ligands may ligate one by one at different $\mathrm{pH}$ (Stepwise mechanism) (eq:3,4). The formation constants of ternary complexes have been determined from the potentiometric titration curves.

$$
\begin{aligned}
& \mathrm{M}+\mathrm{A} \leftrightarrow \mathrm{M}-\mathrm{A} \\
& \mathrm{M}-\mathrm{A}+\mathrm{L} \leftrightarrow \mathrm{M}-\mathrm{A}-\mathrm{L}(4) \\
& \mathrm{M}+\mathrm{A}+\mathrm{L} \leftrightarrow \mathrm{M}-\mathrm{A}-\mathrm{L}
\end{aligned}
$$

Where $\mathrm{A}$ is the primary ligand, $\mathrm{L}$ is the secondary ligand, and $\mathrm{M}$ is a metal ion.

$\log \mathrm{K}^{M(A x)}{ }_{M(A x)(A A)}$ and $\log \mathrm{K}^{M(A A)}{ }_{M(A x)(A A)}$ constants were calculated for each mixed ligand system. They were compared to each other to decide which ligand acts as a primary ligand and which one acts as a secondary ligand [22].

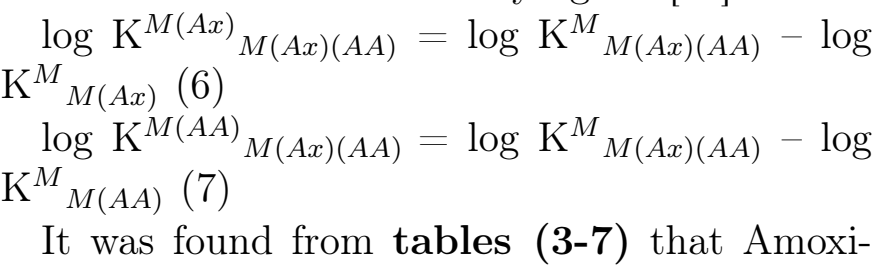
cillin acted as a secondary ligand in ternary complexes involving methionine and asparagine while acting as primary ligands in ternary complexes involving glycine alanine and histidine. DL-alanine ternary complexes' stability was lower than those of glycine complexes, and this isn't due to their basicities because the two amino acids have similar $\mathrm{pKa}_{2}$ values. Instead, it may be due to steric hindrance caused by the methyl group present on the carbon bearing the amino group. Stabilities of the ternary complexes containing asparagine were lower than those of other amino acids, related to the low basicity of the asparagine-free conjugate 

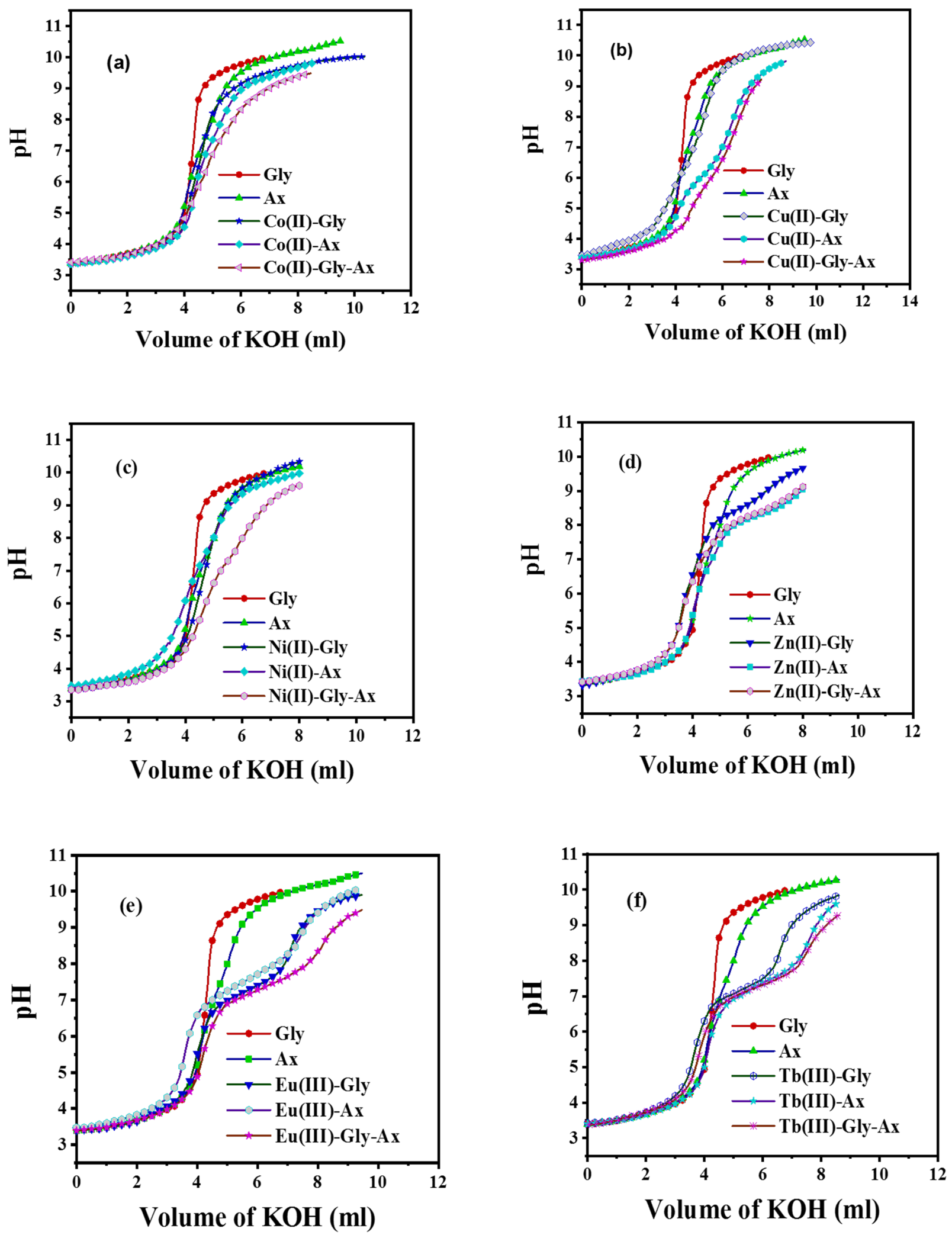

Figure 2: Potentiometric titration curves at $\mathrm{I}=0.1 \mathrm{M} \mathrm{KNO}_{3}$ and $20^{\circ} \mathrm{C}$,for: (a) $\mathrm{Co}(\mathrm{II})-\mathrm{Amoxicillin}-\mathrm{Glycine}$, (b) $\mathrm{Cu}(\mathrm{II})-$ Amoxicillin-Glycine,(c) Ni(II)-Amoxicillin-Glycine, (d) Zn(II)-Amoxicillin-Glycine,(e) Eu(III)-Amoxicillin- Glycine and (f) $\mathrm{Tb}(\mathrm{III})$ - Amoxicillin- Glycine. 

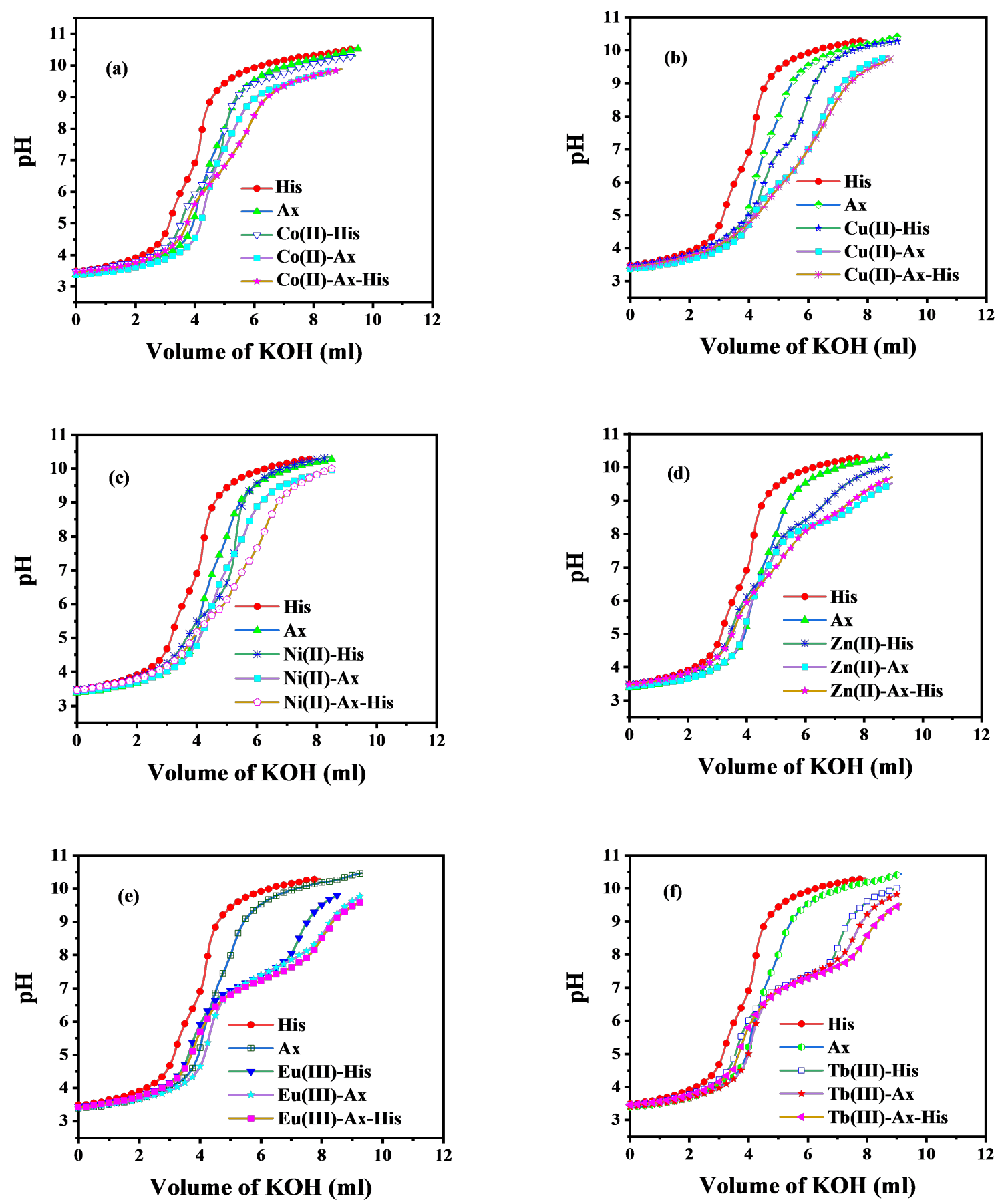

Figure 3: Potentiometric titration curves at $\mathrm{I}=0.1 \mathrm{M} \mathrm{KNO} 3$ and $20^{\circ} \mathrm{C}$, for: (a) $\mathrm{Co}$ (II)-Amoxicillin- Histidine, (b) $\mathrm{Cu}(\mathrm{II})-$ Amoxicillin- Histidine,(c) Ni(II)-Amoxicillin-Histidine,(d) Zn(II)-Amoxicillin-Histidine, (e) Eu(III)Amoxicillin-Histidine and (f) Tb(III)-Amoxicillin-Histidine. 

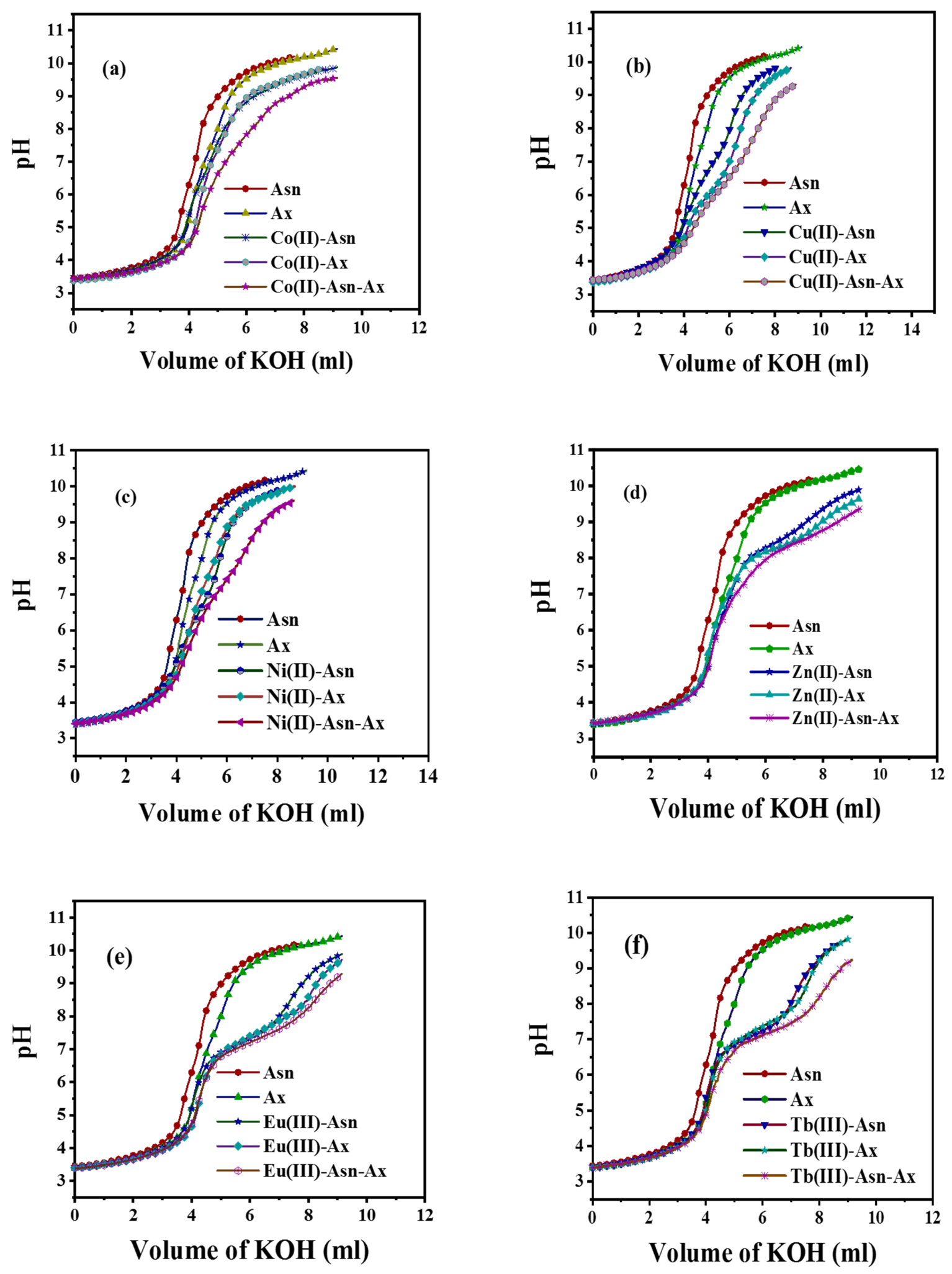

Figure 4: Potentiometric titration curves at $\mathrm{I}=0.1 \mathrm{M} \mathrm{KNO}_{3}$ and $20{ }^{\circ} \mathrm{C}$, for: (a) Co(II)-Asparagine- Amoxicillin, (b) $\mathrm{Cu}(\mathrm{II})$ - Asparagine- Amoxicillin,(c) Ni(II)-Asparagine- Amoxicillin, (d) Zn(II)- Asparagine- Amoxicillin,(e) Eu(III)-Asparagine- Amoxicillin and (f) Tb(III)- Asparagine- Amoxicillin. 

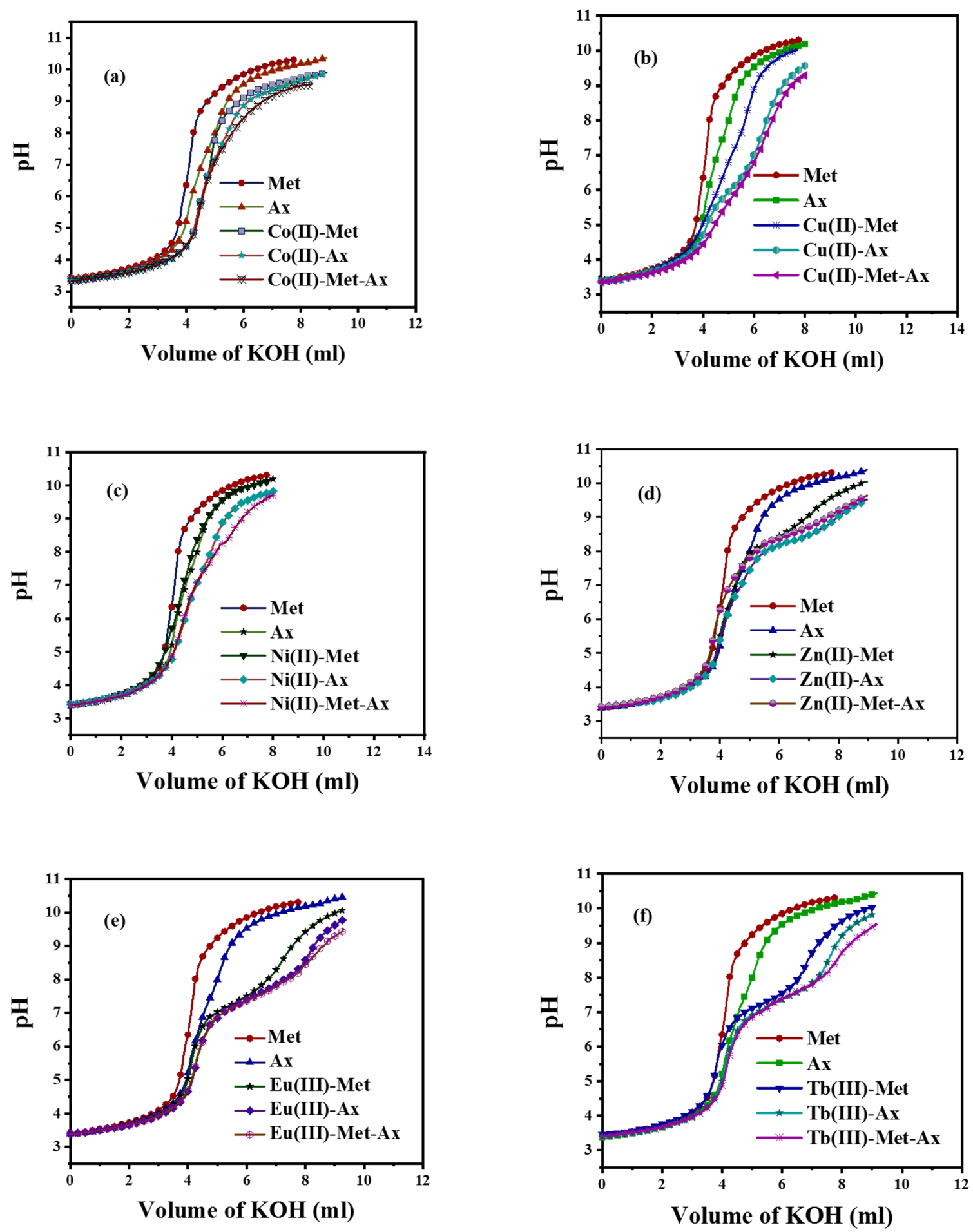

Figure 5: Potentiometric titration curves at $\mathrm{I}=0.1 \mathrm{M} \mathrm{KNO}_{3}$ and $20{ }^{\circ} \mathrm{C}$, for: (a) Co(II)-Methionine Amoxicillin, (b) $\mathrm{Cu}(\mathrm{II})$ - Methionine-Amoxicillin,(c) Ni(II)-Methionine- Amoxicillin, (d) Zn(II)- Methionine- Amoxicillin,(e) Eu(III)-Methionine- Amoxicillin and (f) Tb(III)- Methionine- Amoxicillin. 

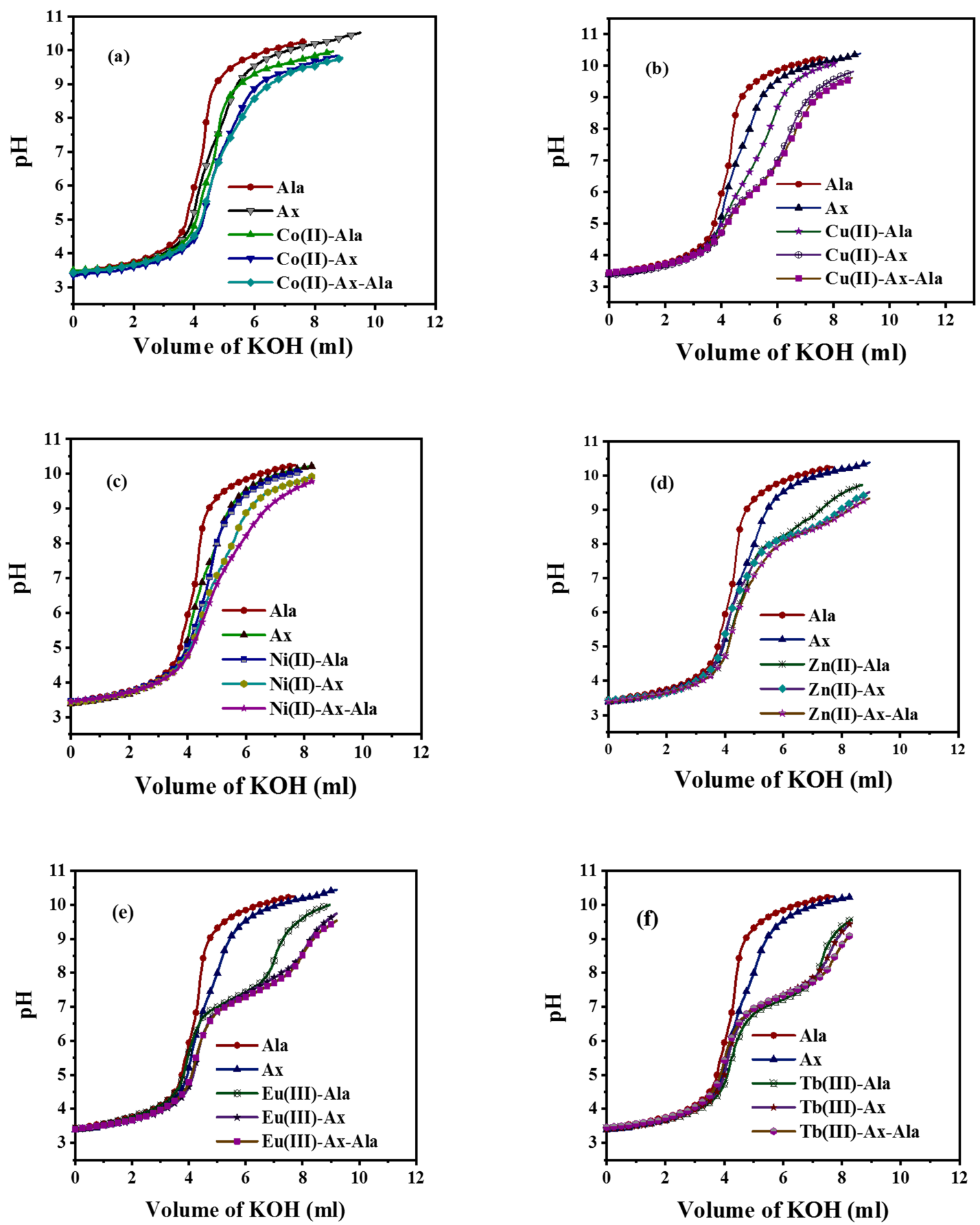

Figure 6: Potentiometric titration curves at $\mathrm{I}=0.1 \mathrm{M} \mathrm{KNO}_{3}$ and $20{ }^{\circ} \mathrm{C}$, for: (a) $\mathrm{Co}$ (II) -Amoxicillin-Alanine,(b) $\mathrm{Cu}(\mathrm{II})$-Amoxicillin- Alanine, (c) Ni(II)-Amoxicillin-Alanine,(d) Zn(II)-Amoxicillin-Alanine,(e) Eu(III)-AmoxicillinAlanine and (f) $\mathrm{Tb}(\mathrm{III})$ - Amoxicillin- Alanine. 
Table 2: Formation constants for the binary complexes of Metal Ions $(\mathrm{M})+$ Amino acids and Amoxicillin at $\mathrm{I}=0.1 \mathrm{M}$ $\mathrm{KNO}_{3}$ and $20^{\circ} \mathrm{C}$.

\begin{tabular}{lcccccc}
\hline \multicolumn{7}{c}{$\log \mathbf{K}$} \\
\hline metal ion & Alanine & Asparagine & Methionine & Histidine & Glycine & Amoxicillin \\
\hline $\mathrm{Cu}(\mathrm{II})$ & 8.37 & 6.70 & 8.15 & 12.0 & 8.50 & 9.46 \\
$\mathrm{Co}(\mathrm{II})$ & 7.29 & 5.96 & 5.05 & 9.75 & 6.55 & 5.77 \\
$\mathrm{Ni}(\mathrm{II})$ & 8.00 & 6.75 & 6.46 & 11.0 & 6.96 & 6.20 \\
$\mathrm{Zn}(\mathrm{II})$ & 7.57 & 6.04 & 6.76 & 7.15 & 7.58 & 6.16 \\
$\mathrm{Eu}(\mathrm{III})$ & 7.76 & 6.34 & 7.43 & 8.17 & 9.80 & 7.43 \\
$\mathrm{~Tb}(\mathrm{III})$ & 7.26 & 6.38 & 7.16 & 8.10 & 7.03 & 7.49 \\
\hline
\end{tabular}

Table 3: Formation constants of ternary $\mathrm{M}+\mathrm{Ala}+\mathrm{Ax}$ systems at $\mathrm{I}=0.1 \mathrm{M} \mathrm{KNO}_{3}$ and $20^{\circ} \mathrm{C}$.

\begin{tabular}{lcccc}
\hline System & $\begin{array}{c}\log \mathrm{K}^{M} \\
M(A x)(A l a)\end{array}$ & $\begin{array}{c}\log \mathrm{K}^{M(A l a)} \\
M(\text { Ax)(Ala })\end{array}$ & $\begin{array}{c}\log \mathrm{K}^{M(A x)} \\
M(A x)(A l a)\end{array}$ & \multicolumn{1}{c}{$\operatorname{logK}$} \\
\hline $\mathrm{Co}(\mathrm{II})-A x-A l a$ & 11.57 & 4.28 & 5.80 & -1.49 \\
$\mathrm{Cu}(\mathrm{II})-A x-A l a$ & 14.68 & 6.31 & 5.22 & -3.15 \\
$\mathrm{Ni}(\mathrm{II})-A x-A l a$ & 11.99 & 3.99 & 5.79 & -2.21 \\
$\mathrm{Zn}(\mathrm{II})-A x-A l a$ & 13.54 & 5.97 & 7.38 & -0.19 \\
Eu(III)-Ax-Ala & 15.10 & 7.34 & 7.67 & -0.09 \\
Tb(III)-Ax-Ala & 15.04 & 7.78 & 7.55 & 0.29 \\
\hline
\end{tabular}

Table 4: Formation constants of ternary $\mathrm{M}+\mathrm{Gly}+\mathrm{Ax}$ systems at $\mathrm{I}=0.1 \mathrm{M} \mathrm{KNO}_{3}$ and $20^{\circ} \mathrm{C}$.

\begin{tabular}{lcccc}
\hline System & $\log \mathrm{K}^{M}$ & $\log \mathrm{K}^{M(G l y)}$ & $\log \mathrm{K}^{M(A x)}$ & $\Delta \operatorname{logK}$ \\
& $M(A x)($ Gly $)$ & $M(A x)($ Gly $)$ & $M(A x)(G l y)$ & \\
\hline Co(II)-Ax-Gly & 12.10 & 5.55 & 6.33 & -0.22 \\
Cu(II)-Ax-Gly & 14.94 & 6.44 & 5.48 & -3.02 \\
Ni(II)-Ax-Gly & 12.23 & 5.27 & 6.03 & -0.93 \\
Zn(II)-Ax-Gly & 12.87 & 5.42 & 6.88 & -0.87 \\
Eu(III)-Ax-Gly & 15.12 & 5.32 & 7.69 & -2.11 \\
Tb(III)-Ax-Gly & 15.04 & 8.01 & 7.55 & 0.52 \\
\hline
\end{tabular}

Table 5: Formationconstants of ternary $\mathrm{M}+\mathrm{His}+\mathrm{Ax}$ systems at $\mathrm{I}=0.1 \mathrm{M} \mathrm{KNO}_{3}$ and $20^{\circ} \mathrm{C}$.

\begin{tabular}{|c|c|c|c|c|}
\hline System & $\begin{array}{l}\log \mathrm{K}^{M} \\
M(H i s)(A x)\end{array}$ & $\begin{array}{r}\log \mathrm{K}^{M(H i s)} \\
M(H i s)(A x)\end{array}$ & $\begin{array}{r}\log \mathrm{K}^{M(A x)} \\
\quad M(H i s)(A x)\end{array}$ & $\Delta \log \mathrm{K}$ \\
\hline $\mathrm{Co}(\mathrm{II})-\mathrm{Ax}$-His & 13.3 & 3.55 & 7.53 & -2.22 \\
\hline $\mathrm{Cu}(\mathrm{II})-\mathrm{Ax}-\mathrm{His}$ & 16 & 4.00 & 6.54 & -5.46 \\
\hline $\mathrm{Ni}(\mathrm{II})-\mathrm{Ax}-\mathrm{His}$ & 14.33 & 2.92 & 7.72 & -2.87 \\
\hline $\mathrm{Zn}(\mathrm{II})-\mathrm{Ax}-\mathrm{His}$ & 15.18 & 7.90 & 8.93 & 1.87 \\
\hline $\mathrm{Eu}(\mathrm{III})-\mathrm{Ax}-\mathrm{His}$ & 17.11 & 8.94 & 9.68 & 1.51 \\
\hline $\mathrm{Tb}$ (III)-Ax-His & 17.07 & 8.97 & 9.58 & 1.48 \\
\hline
\end{tabular}


Table 6: Formation constants of ternary $\mathrm{M}+\mathrm{Asn}+\mathrm{Ax}$ systemsat $20^{\circ} \mathrm{C}, \mathrm{I}=0.1 \mathrm{M} \mathrm{KNO}$

\begin{tabular}{lcccc}
\hline System & $\log \mathrm{K}^{M}$ & $\log \mathrm{K}^{M(A s n)}$ & $\log \mathrm{K}^{M(A x)}$ & $\Delta \log$ \\
& $M(A s n)(A x)$ & $M(A s n)(A x)$ & $M(A s n)(A x)$ & \\
\hline $\mathrm{Co}(\mathrm{II})-A s n-A x$ & 12.03 & 6.07 & 6.26 & 0.30 \\
$\mathrm{Cu}(\mathrm{II})-$ Asn-Ax & 13.23 & 6.53 & 3.77 & -2.93 \\
$\mathrm{Ni}(\mathrm{II})-$ Asn-Ax & 12.85 & 6.10 & 6.65 & -0.10 \\
$\mathrm{Zn}(\mathrm{II})-$ Asn-Ax & 12.36 & 6.26 & 6.18 & 0.16 \\
$\mathrm{Eu}(\mathrm{III})-A s n-A x$ & 13.75 & 7.41 & 6.32 & -0.02 \\
$\mathrm{~Tb}(\mathrm{II})-$ Asn-Ax & 13.72 & 7.34 & 6.23 & -0.15 \\
\hline
\end{tabular}

Table 7: Formation constants of ternary $\mathrm{M}+\mathrm{Met}+$ Ax systems at $20 \quad{ }^{\circ} \mathrm{C}, \mathrm{I}=0.1 \mathrm{M} \mathrm{KNO}$

\begin{tabular}{lcccc}
\hline System & $\log \mathrm{K}^{M}$ & $\log \mathrm{K}^{M(M e t)}$ & $\log \mathrm{K}^{M(A x)}$ & $\Delta \operatorname{logK}$ \\
& $M(M e t)(A x)$ & $M(M e t)(A x)$ & $M(M e t)(A x)$ & \\
\hline Co(II)-Met-Ax & 11.78 & 6.73 & 6.01 & 0.96 \\
Cu(II)-Met-Ax & 14.93 & 6.78 & 5.47 & -2.68 \\
Ni(II)-Met-Ax & 11.9 & 5.9 & 6.16 & -0.76 \\
Zn(II)-Met-Ax & 12.58 & 5.82 & 6.46 & 0.34 \\
Eu(III)-Met-Ax & 14.91 & 7.38 & 7.38 & 0.05 \\
Tb(III)-Met-Ax & 14.85 & 7.61 & 7.28 & 0.20 \\
\hline
\end{tabular}

base $(\mathrm{pKa}=8.82)$. The higher stabilities of histidine complexes showed that histidine interacted with the metal ions through amino and imidazole nitrogen to form a six-membered ring [23], other amino acids ligated through amino and carboxylic groups and formed a five-membered ring. The complex stabilities of the ternary systems to the metal ion were:

a- For transition metal ions: $\mathrm{Zn}(\mathrm{II})<\mathrm{Cu}(\mathrm{II})>$ $\mathrm{Ni}(\mathrm{II})>\mathrm{Co}(\mathrm{II})$, which follow the Iriving-Williams series, this order could be attributed to ionization potential and ionic radii of metal ions [24].

b- For lanthanide metal ions: $\mathrm{Eu}(\mathrm{III})>$ $\mathrm{Tb}$ (III), the formation constant of the $\mathrm{Ln}$ (III) complexes decreases slightly with increasing atomic number [25].

The greater stability of $\mathrm{Cu}(\mathrm{II})$ complexes could be assigned with Jahn-Teller effect [26]. On the other hand, Zn(II)has $\mathrm{d}^{10}$ fully occupied d-orbital has low potency to accept electrons from ligands; hence it has lower stability constant. During the titration, no precipitation occurred, indicating that there is no possibility of hydrolysis of the studied metal ions in the presence of excess lig- and. This showed that the amino acids tend to form more stable metal complexes in the solution. The ternary complexes' stability was compared with those of the corresponding binary complexes using the $\Delta \log K$ values. The values of $\Delta \log K$ are determined by Equation (8):

$\Delta \log \mathrm{K}=\log \mathrm{K} \quad M(A A)(A x) \quad-\left(\log \mathrm{K}_{M(A A)} \quad+\right.$ $\left.\log \mathrm{K}_{M(A x)}\right)$. (8)

The positive $\Delta \log \mathrm{K}$ value for the complexes indicates that the ternary complexes are more stable than the corresponding binary complexes. In contrast, the negative $\Delta \log \mathrm{K}$ value for the complexes indicates that the ternary complexes are less stable than the corresponding binary complexes (binary complexes are preferred). Negative values can be explained based on the presence of a fewer number of coordination sites on the binary complexes.

The concentration distribution of the various species as a function of $\mathrm{pH}$ provides a useful description of metal ion binding in the biological system. In the present work, the concentration of the formed complexes increases with increasing 
(a)

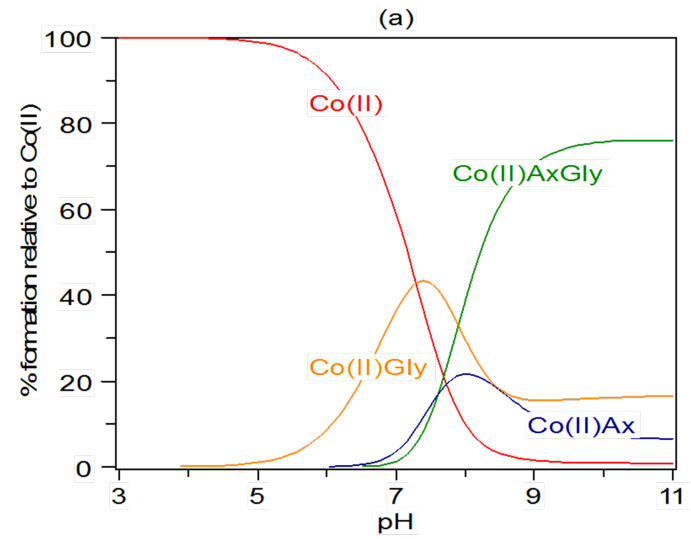

(c)

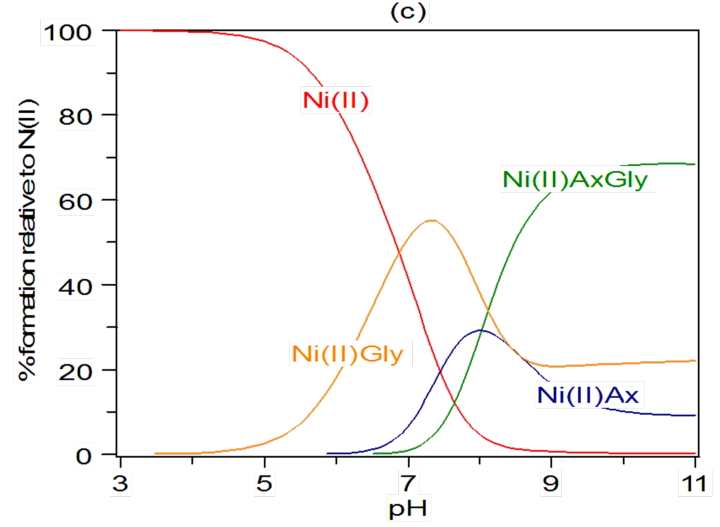

(e)

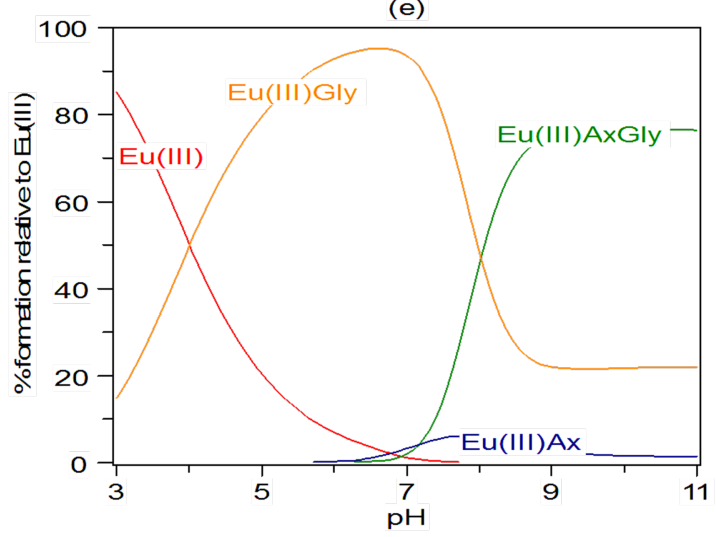

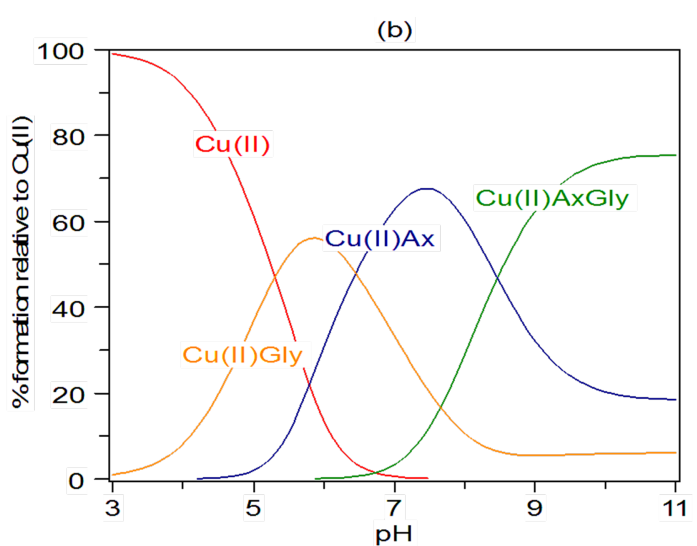

(d)

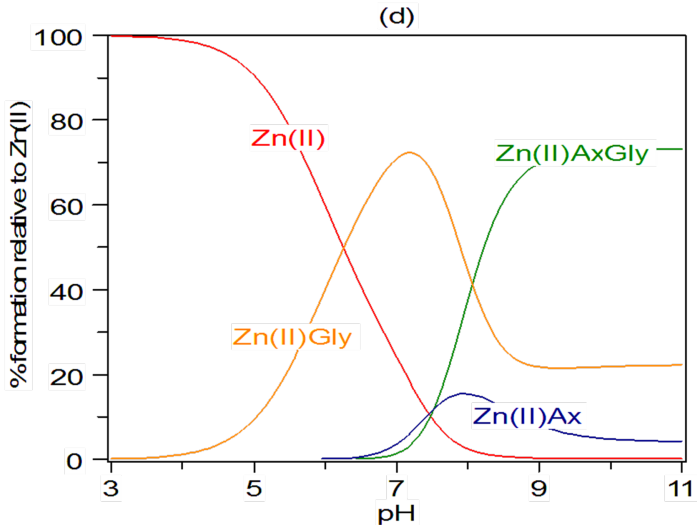

(f)

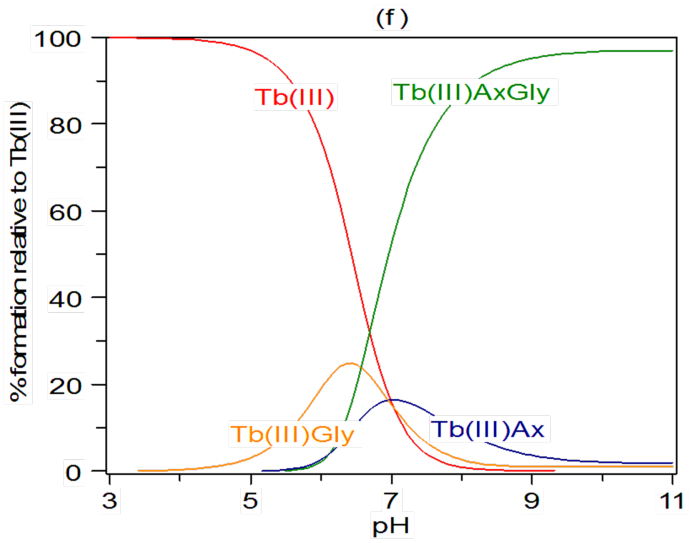

Figure 7: Concentration distribution of various species asa function of $\mathrm{pH}$ in : (a) Co(II)-Amoxicillin- Glycine ternary system,(b) $\mathrm{Cu}(\mathrm{II})$-Amoxicillin- Glycineternary system,(c) Ni(II)-Amoxicillin-Glycineternary system, (d) $\mathrm{Zn}(\mathrm{II})$-Amoxicillin- Glycine ternary system, (e)Eu(III)-Amoxicillin- Glycine ternary system, (f) Tb(III)-AmoxicillinGlycine ternary system 

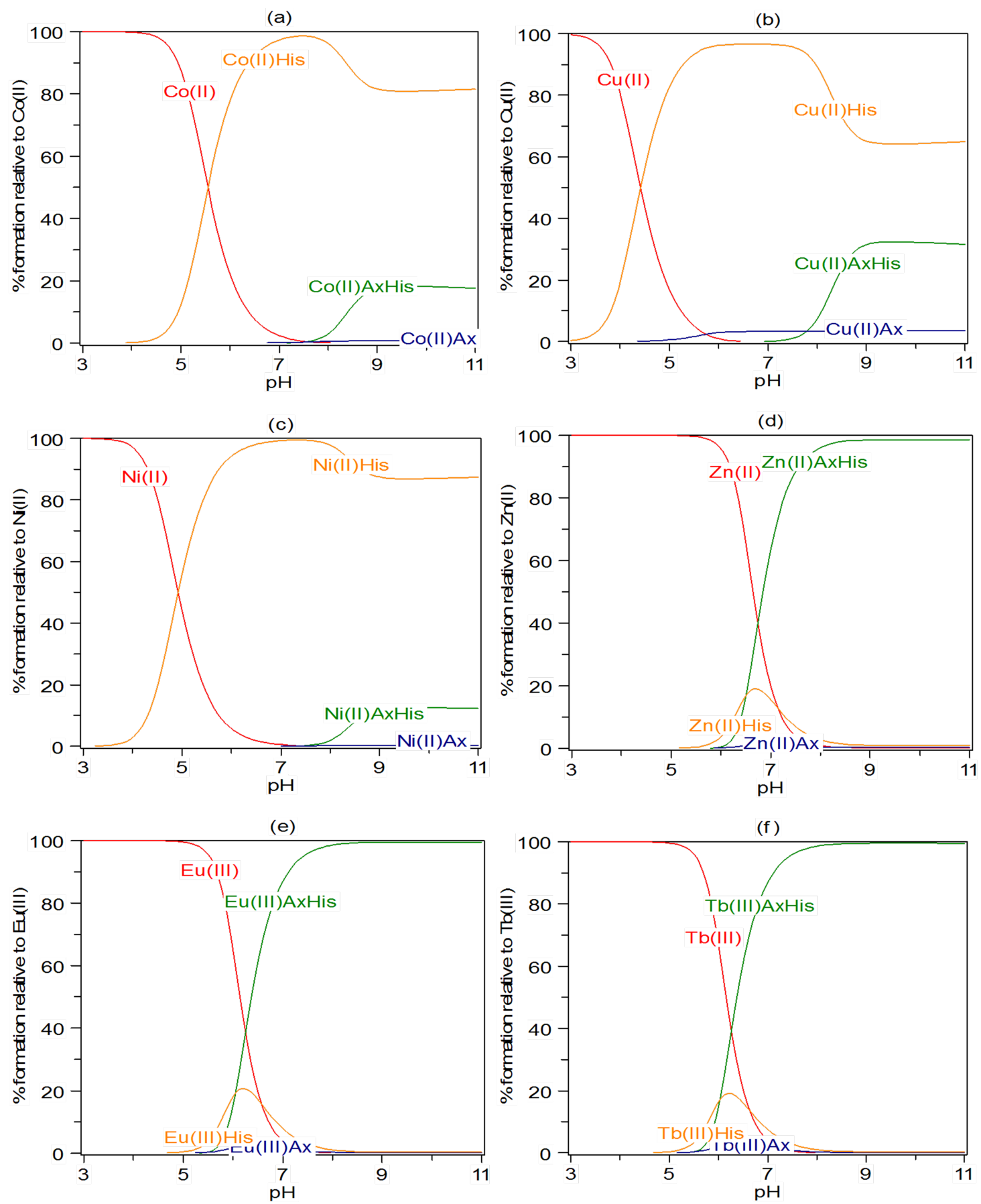

Figure 8: Concentration distribution of various species as a function of $\mathrm{pHin}$ : (a) Co(II)-Amoxicillin-Histidine ternary system,(b) $\mathrm{Cu}$ (II) -Amoxicillin-Histidine ternary system,(c) Ni(II)-Amoxicillin-Histidine ternary system, (d)Zn(II)Amoxicillin -Histidine ternary system, (e) Eu(III)-Amoxicillin-Histidine ternary system, (f) Tb(III) -AmoxicillinHistidine ternary system . 

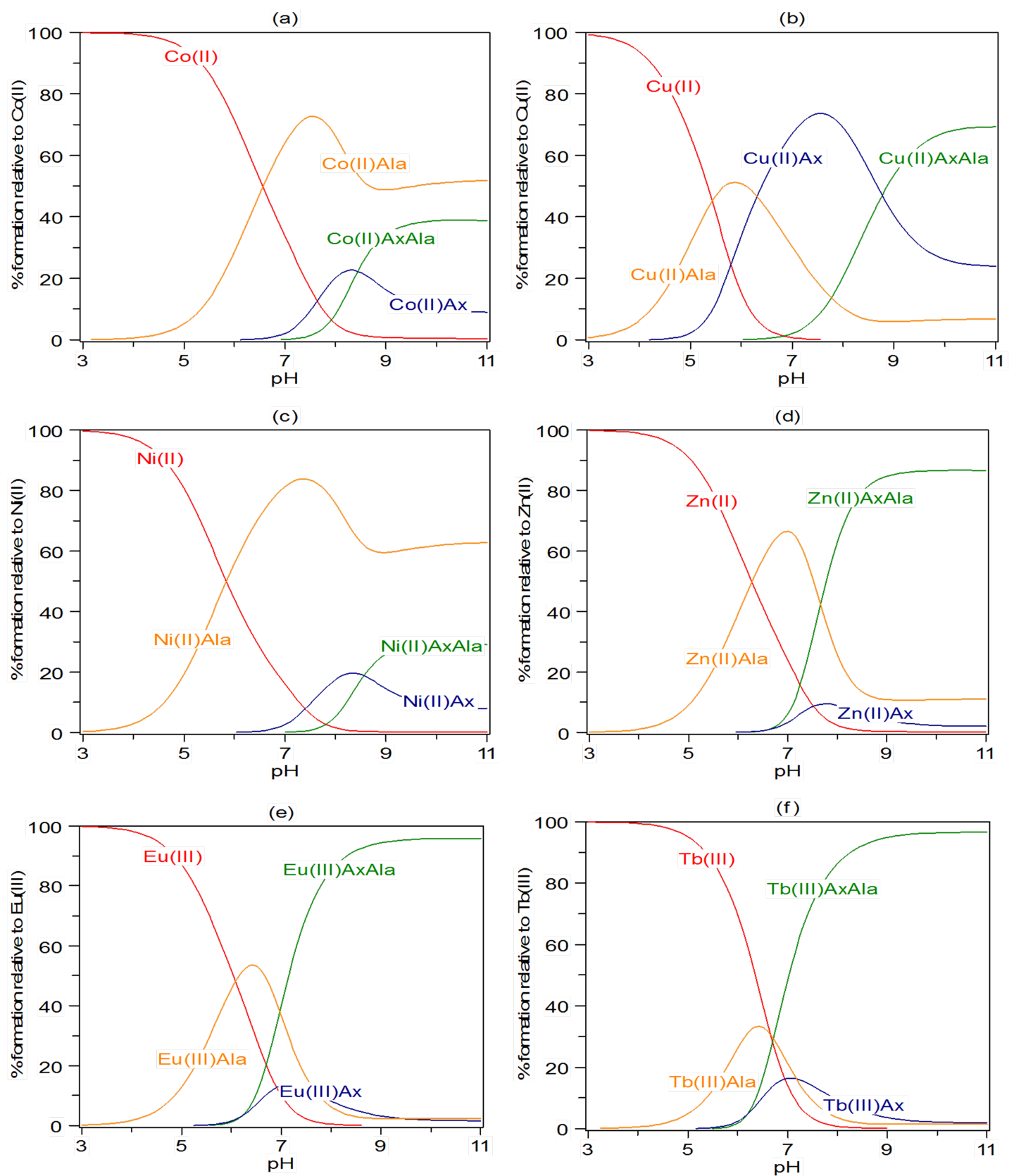

Figure 9: Concentration distribution of various species asa function of $\mathrm{pH}$ in : (a) $\mathrm{Co}$ (II) -Amoxicillin-Alanine ternary system,(b) $\mathrm{Cu}$ (II)-Amoxicillin-Alanine ternary system,(c) Ni(II)-Amoxicillin-Alanine ternary system, (d) Zn(II)-AmoxicillinAlanine ternary system, (e) Eu(III)-Amoxicillin-Alanine ternary system, (f) Tb(III)-Amoxicillin-Alanine ternary system 

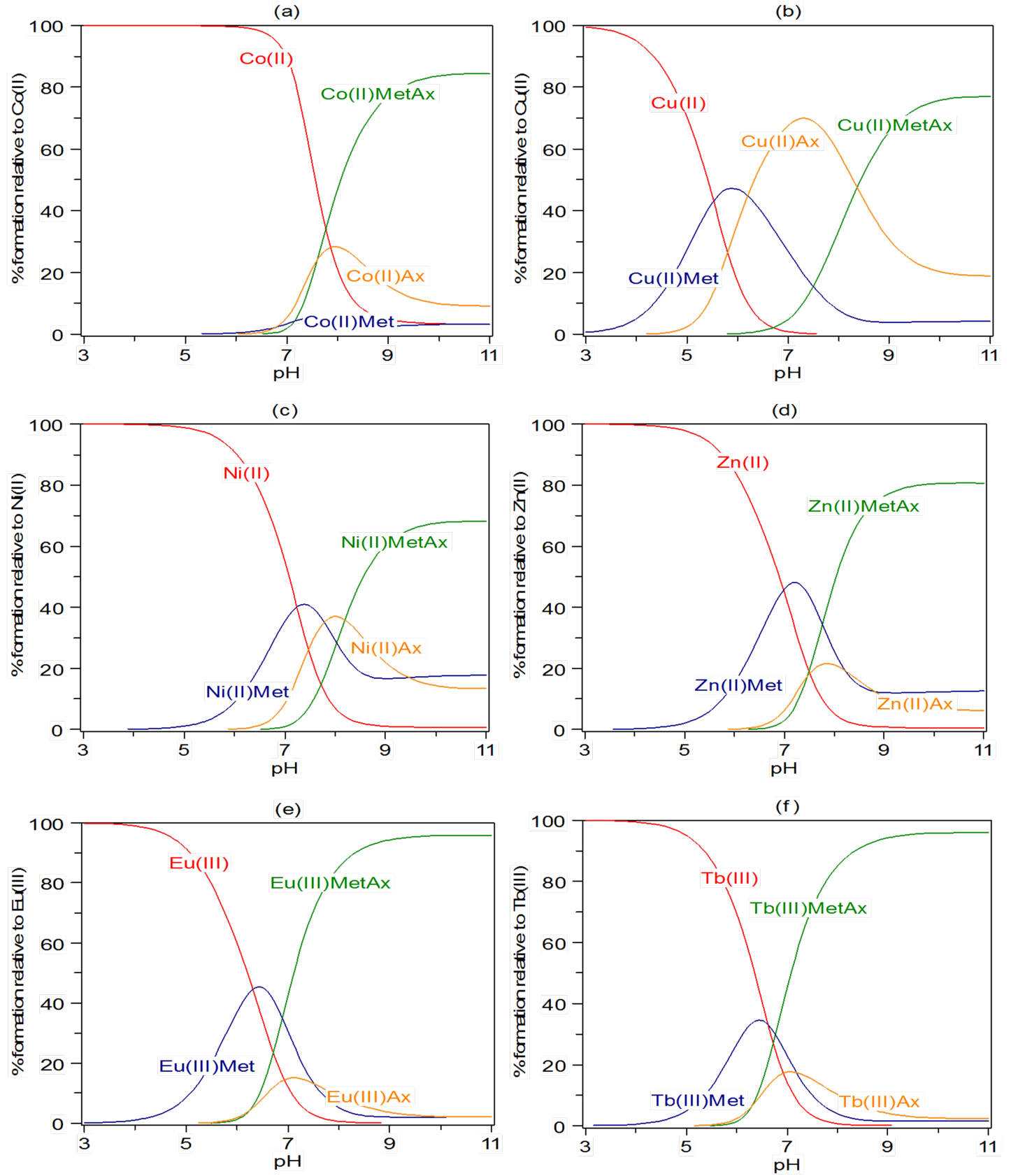

Figure 10: Concentration distribution of various species asa function of $\mathrm{pH}$ in : (a) Co(II)-Methionine-Amoxicillin ternary system,(b) $\mathrm{Cu}$ (II)-Methionine-Amoxicillin ternary system,(c) Ni(II)- Methionine-Amoxicillin ternary system, (d) Zn(II)-Methionine-Amoxicillin ternary system, (e) Eu(III)- Methionine-Amoxicillin ternary system, (f) Tb(III)Methionine -Amoxicillin ternary system 

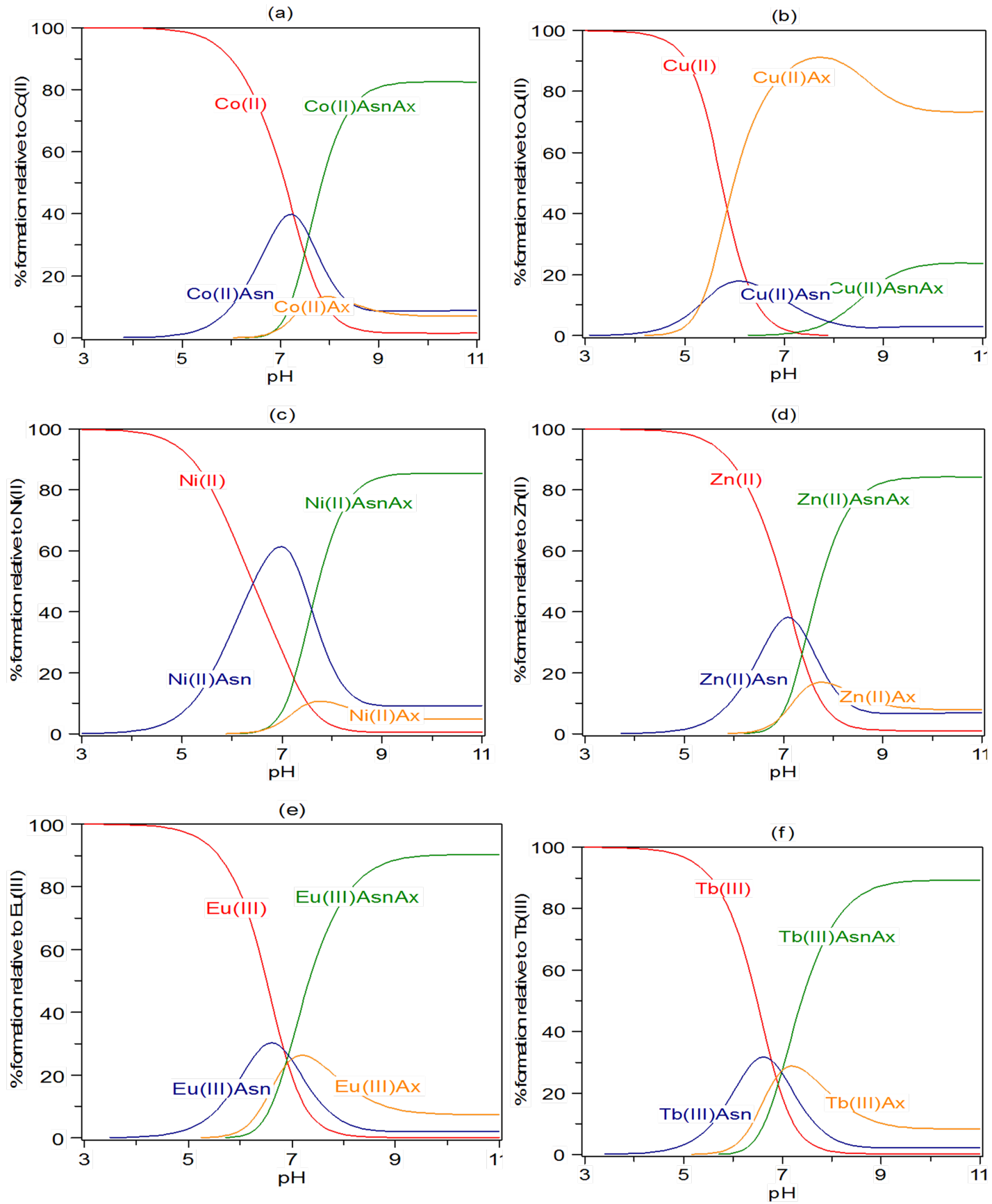

Figure 11: Concentration distribution of various species as a function of $\mathrm{pH}$ in : (a) $\mathrm{Co}(\mathrm{II})$-Asparagine-Amoxicillin ternary system,(b) $\mathrm{Cu}$ (II)-Asparagine-Amoxicillin ternary system,(c) Ni(II)-Asparagine-Amoxicillin ternary system, (d) Zn(II)- Asparagine -Amoxicillin ternary system, (e) Eu(III)-Asparagine -Amoxicillin ternary system, (f) Tb(III)Asparagine-Amoxicillin ternary system 
$\mathrm{pH}$, making the formation of complexes more favored in the physiological $\mathrm{pH}$ range. Distribution curves of all the binary and ternary systems of $\mathrm{Cu}(\mathrm{II}), \mathrm{Co}(\mathrm{II}), \mathrm{Ni}(\mathrm{II}), \mathrm{Zn}(\mathrm{II}), \mathrm{Eu}(\mathrm{III})$, and $\mathrm{Tb}(\mathrm{III})$ were drawn by the HYSS computer program and are given in Figures( $\mathbf{7 - 1 1})$. In figure(7): metal ions were $100 \%$ at the beginning, as reaction proceeded and $\mathrm{pH}$ increased, its concentration decreased and binary complexes started to form and had grown until reached maximum values $(50 \%$ at $\mathrm{pH} \quad 5.9),(70 \%, \mathrm{pH}$ 7.5),(80\%,pH 7.5),(70\%,pH 7), (70\%,pH 6.5) and $(30 \%, \mathrm{pH} 6.5)$ for $(\mathrm{Cu}(\mathrm{II}), \mathrm{Co}(\mathrm{II}), \mathrm{Ni}(\mathrm{II})$, $\mathrm{Zn}(\mathrm{II}), \mathrm{Eu}(\mathrm{III})$ and $\mathrm{Tb}(\mathrm{III})$-Ala binary systems respec tively, while binary systems of amoxicillin reached maximum values $(70 \%, \mathrm{pH} 7.7),(20 \%, \mathrm{pH}$ 8.2), (20\%, pH 8.5), (10\%,pH 8), (25\%,pH 7.5) and $(15 \%, \mathrm{pH} 7.1)$ for $(\mathrm{Cu}(\mathrm{II}), \mathrm{Co}(\mathrm{II}), \mathrm{Ni}(\mathrm{II})$, $\mathrm{Zn}(\mathrm{II}), \mathrm{Eu}(\mathrm{III})$ and $\mathrm{Tb}(\mathrm{III})$ respectively. As $\mathrm{pH}$ increased more, concentrations of binary complexes decreased as they dissociated to form ternary complexes. Ternary complexes began to form at $\mathrm{pH} 7.1,7,7.9,7.0,6.3$ and reached maximum values $(70 \%, \mathrm{pH} 10),(39 \%, \mathrm{pH} 9.9),(30 \%$, $\mathrm{pH} 9.5),(80 \%, \mathrm{pH} 9.5),(90 \%, \mathrm{pH} 9)$ and $(95 \%$, $\mathrm{pH}$ 10) for (Cu(II), $\mathrm{Co}(\mathrm{II}), \mathrm{Ni}(\mathrm{II}), \mathrm{Zn}(\mathrm{II}), \mathrm{Eu}(\mathrm{III})$ and $\mathrm{Tb}$ (III)-Ala-Ax complexes respectively.

\section{Conclusion}

Ternary complexes of amoxicillin with amino acids and metal ions were studied potentiometrically to determine their stability constants which could provide information about the ability of ligands to form complexes and the activities of the formed complexes, used for biological applications. Ternary complexes were formed in association manner. Stability constants were found to follow the order $\mathrm{Zn}(\mathrm{II})<\mathrm{Cu}(\mathrm{II})>\mathrm{Ni}(\mathrm{II})>\mathrm{Co}(\mathrm{II})$ for transition metal ions and $\mathrm{Eu}(\mathrm{III})>\mathrm{Tb}(\mathrm{III})$ for lanthanide metal ions. In the present paper, some ternary complexes are more stable than the corresponding binary complexes. The concentration distribution diagrams of all species formed in solution were investigated and discussed.

\section{References}

[1] R. Tabti, N. Tounsi, C. Gaiddon, E. Bentouhami, L. Desaubry, Progress in copper complexes as anticancer agents, 2017, pp. 7-7. doi:10.4172/21610444.1000445 .

[2] D. Charles, J. H. Turner, C. Redmond, Karyo typic profiles of women after clomiphene citrate Therapy, || International Journal of Obstetrics and Gynecology 80 (2005) 264-270.

[3] P. J. Sorbie, R. P. Marrero, The use of clomiphene citrate in male infertility, J. Urol 131 (1984).

[4] G. D. Palmer, M. J. Stoddart, E. Gouze, J. N. Gouze, S. C. Ghivizzani, R. M. Porter, C. H. Evans, A simple, lanthanide-based method to enhance the transduction efficiency of adenovirus vectors, Gene Ther 15 (2008). doi:10.1038/sj.gt.3303092.

[5] Journal of the Chemical Society (1970). doi:10.1039/j3970000x001.

[6] J. M. Pratt (1972).

[7] S. Regupathy, M. S. Nair, Studies on some ternary complexes of copper(II) involving an amino penicillin drug, J. Saudi Chem. Soc 16 (2012) 247-256. doi:10.1016/j.jscs.2011.01.005.

[8] J. J. Platteeuw, Resistance to sulphadrug-based antifolate therapy in malaria: are we looking in the right place?, Trop. Med. Int. Heal 11 (2006) 804-808. doi:10.1111/j.1365-3156.2006.01646.x.

[9] J. Zhang, Q. Shi, Determination of Stability Constants of Cadmium-Glycine Complexes by a Unified Treatment for Potentiometric and Polarographic Data, Chinese J. Chem. Phys 19 (2006) 164-168. doi:10.1360/cjcp2006.19(2).164.5.

[10] G. Anderegg, F. Arnaud-Neu, R. Delgado, J. Felcman, K. Popov, Critical evaluation of stability constants of metal complexes of complexones for biomedical and environmental applications* (IUPAC Technical Report), Pure Appl. Chem 77 (2005) 1445-1495. doi:10.1351/pac200577081445.

[11] V. Soundaranayaki, A. Kulandaisamy, A. Arunadevi, Synthesis, structural, pharmacological and molecular docking simulations studies of some transition metal complexes, Inorg. Chem. Commun 122 (2020) 108271-108271. doi:10.1016/j.inoche.2020.108271.

[12] A. A. Abou-Hussein, W. Linert, Synthesis, spectroscopic, coordination and biological activities of some organometallic complexes derived from thio-Schiff base ligands, Spectrochim. Acta Part A Mol. Biomol. Spectrosc 117 (2014) 763-771. doi:10.1016/j.saa.2013.06.078.

[13] Z. H. Chohan, H. Pervez, A. Rauf, K. M. Khan, C. T. Supuran, Isatin-derived Antibacterial and Antifungal Compounds and their Transition Metal Complexes, J. Enzyme Inhib. Med. Chem 19 (2004) 417-423. doi:10.1080/14756360410001710383.

[14] J. R. Anacona, N. Ramos, G. D. D. Delgado, E. M. Roque, Coordination Behavior of Sulfathiazole: Crys- 
tal Structure of, Antibacterial activity 55 (2002) 901908. doi:10.1080/0095897022000002222.

[15] A. As, E. Al, I. Ym, Colorimetric determination of amoxicillin in pure form and in pharmaceutical preparations, Talanta (1994) 41-41.

[16] V. G. Alekseev, O. I. Lyamtseva, I. S. Samuilova, Complexation of managanese(II), cobalt(II), nickel(II), zink(II), and cadmium(II) cations with amoxicillin, Russ. J. Inorg. Chem 52 (2007) 383-385. doi:10.1134/S0036023607030151.

[17] K. Smerkova, K. Dolezelikova, L. Bozdechova, Z. Heger, L. Zurek, V. Adam, Nanomaterials with active targeting as advanced antimicrobials 12 (2020). doi:10.1002/wnan.1636.

[18] B. Nagaralli, J. Seetharamappa, M. Melwanki, Sensitive spectrophotometric methods for the determination of amoxycillin, ciprofloxacin and piroxicam in pure and pharmaceutical formulations, J. Pharm. Biomed. Anal 29 (2002) 859-864.

[19] S. V. Lapshin, V. G. Alekseev, Copper(II) complexation with ampicillin, amoxicillin, and cephalexin, Russ. J. Inorg. Chem 54 (2009) 1066-1069. doi:10.1134/S0036023609070122.

[20] T. M. Mwene-Mbeja, Chemical Stability of Pharmaceutical Organic Compounds, Am. J. Biomed. Sci. Res 6 (2019) 14-22. doi:10.34297/AJBSR.2019.06.000984.

[21] A. B. Patil, Stability Constants of Ternery Complexes of Transition Metal(II) ions with Aspartic Acid and Glutamic Acid as Primary Ligands and Ampicillin and Cephalexin as Secondary Ligands, Orient. J. Chem 28 (2012) 1509-1512. doi:10.13005/ojc/280357.

[22] A. M. Al-Mohaimeed, A. A. Alothman, Characterization by Potentiometric Procedures of the Stability Constants of the Binary and Ternary Complexes of $\mathrm{Cu}(\mathrm{II})$ and Duloxetine Drug with Amino Acids, J. Chem 2019 (2019) 1-13. doi:10.1155/2019/1064942.

[23] N. Türkel, Equilibrium Study of the Mixed Complexes of Copper(II) with Adenine and Amino Acids in Aqueous Solution, J. Solution Chem 44 (2015) 1267-1280. doi:10.1007/s10953-015-0344-y.

[24] K. Ishola, M. Oladipo, O. Odedokun, O. T. Olanipekun, Potentiometric Studies of Stability Constants and Speciation of Binary and Ternary Complexes of Metal (II) Ions with Amino Acids and Thiobarbituric Acid, Am. J. Appl. Chem 8 (2020) 23-23. doi:10.11648/j.ajac.20200801.14.

[25] A. S. Orabi, Physicochemical Properties of Ampicillin and Amoxicillin as Biologically Active Ligands with Some Alkali Earth, Transition Metal, and Lanthanide Ions in Aqueous and Mixed Solvents at 20, 30, and 40?C, J. Solution Chem 34 (2005) 95-111. doi:10.1007/s10953-005-2075-y.

[26] C. F. Macrae, I. J. Bruno, J. A. Chisholm, P. R. Edgington, P. Mccabe, E. Pidcock, L. Rodriguez-Monge, R. Taylor, J. V. D. Streek, P. A. Wood, Mercury CSD
2.0 - new features for the visualization and investigation of crystal structures, J. Appl. Crystallogr 41 (2008) 466-470. doi:10.1107/S0021889807067908. 